Available online at

INSECTA

Integrative Science Education and Teaching Activity Journal

Journal homepage : https://jurnal.iainponorogo.ac.id/index.php/insecta

\title{
Research Article \\ Development of Booklet Based Science Learning Media for Junior High School
}

\author{
Cips Nur Aini ${ }^{*}$, Mohammad Wildan Habibi ${ }^{2}$ \\ ${ }^{1}$ Institut Agama Islam Negeri (IAIN) Jember,Jember, Indonesia \\ ${ }^{2}$ Institut Agama Islam Negeri (IAIN) Jember,Jember, Indonesia
}

* Corresponding Address: cipsnuraini11 @ gmail.com

\section{Article Info \\ Article history: \\ Received: October 6, 2020 \\ Accepted: October 28, 2020 \\ Published: November 27, 2020}

\section{Keywords:}

booklet, Natural Science

Development

\begin{abstract}
This research is motivated by the low interest in student learning in science subjects, especially class VII Biology material which assumes that Biology material is identical to a lot of writing in books and contains a lot of memorization, educators have not used school facilities to develop learning media and minimal teaching materials are only in the form of worksheets. Students are not interested in learning science. The school is a pesantrenbased school, where students only get information from the LKS and the material delivered by the teacher. One of the interesting learning media is the booklet- based science learning media. This study aims to determine the validity of booklet media and student responses to booklet media. The type of research used is Research and Development which refers to the 4D development model (Define, Design, Development, and Dissemination) from S. Thiangarajan (1974) which has been modified into 3D. The results showed that the results of the material expert validation obtained a percentage of $92 \%$; media experts obtained a percentage of $97.77 \%$; by science teachers obtained a percentage of $100 \%$. Small-scale trials obtained a percentage of $91.06 \%$ and large-scale trials obtained a percentage of $92.72 \%$. This it can be concluded that the booklet- based science learning media on the material of the interaction of living things with their environment is valid to be used as a media for learning science biology in class VII MTs / SMP
\end{abstract}

(C) 2020 Tadris Ilmu Pengetahuan Alam Department, IAIN Ponorogo, Indonesia.

\section{INTRODUCTION}

Education cannot be separated from the curriculum which is the basic guideline in the teaching and learning process in the world of education. The success of an education and the success of students in learning is based on the implemented curriculum (Adelina, 2018). Various attempts have been made by the government to improve the curriculum in Indonesia by revising it from the KTSP curriculum to the 2013 curriculum. The 2013 curriculum has a student-centered learning system. In learning, students must be more active than teachers. So that students look for problems and find answers to the problems themselves which are guided 
by the teacher as a facilitator. However, in general, personnel in Indonesia are still verbal and the learning process is very teacher-centered ( teacher centered learning) (Agustini, 2015).

The objectives of the 2013 curriculum at the SMP education unit level include factual, conceptual and procedural knowledge related to real phenomena and events, so that students are able to interact effectively with the social and natural environment, and act effectively and creatively in abstract and concrete realms. Real phenomena and events, one of which can be shown in the material the interaction of living things with their environment. This material contains phenomena regarding the interaction of living things with their environment, besides that the material is also real or is around the student's environment.

Biology is one of the science materials that students often complain about because the material that has to be studied is very much and many students think that Biology material is identical to many writings in books and contains a lot of memorization. In order for students to easily understand science material, especially biology in class, this requires creative teachers. Creative teachers are able to find something unique and different or new ideas for the advancement of themselves and students. Many factors affect the learning process which does not run effectively, one of these factors is the lack of variety in learning media (Paramita, 2018).

Learning media is a tool to convey teacher messages to students, so that it can stimulate thoughts, feelings, attention, and interests of students to learn (Tafonao, 2018). In the teaching and learning process, the existence of media has an important meaning. Because in these activities the obscurity and complexity of the materials to be delivered to students can be helped and simplified by presenting the media (Syaiful, 2006).

Regarding learning media, the word media comes from Latin "Medius" which literally means "middle", "intermediary" or "introduction". In Arabic "Wasaaila" or an introduction to a message from the sender to the recipient of the message. So, media is a tool that can convey or deliver teaching messages (Nurrita, 2018). Media is a messenger technology that can be used for learning purposes. There are media that are used by teachers ( by utilization) in activities learning, meaning that the media is made by certain parties (media producers) and the teacher just uses it directly in learning activities. besides that, we can also design and make our own media ( by design) according to the abilities and needs of students.

According to Yusufhadi Miarso, learning media is anything that is used to transmit messages and can stimulate the students' thoughts, feelings, attention and willingness so thatthey can encourage a deliberate, purposeful and controlled learning process (Tumbur, 2015). Meanwhile, according to Azhar Arsyad, learning media is anything that is used to convey messages or information in the teaching and learning process so that it can stimulate students' attention and interest in learning (Arsyad, 2004).

Based on the descriptions of these experts, it can be concluded that learning media is a tool that can help the learning process so that the meaning of the message conveyed makes it clearer and learning objectives can be achieved effectively and efficiently.

Basically, the main function of learning media is as a learning resource. Function Other functions are the result of consideration of the general characteristics it has, the language used to convey the message and the impact or effect it has. The general characteristics of the media in question are its ability to record, store, preserve, reconstruct and transport an event or object. Then what is meant by the language used to convey messages is verbal language and nonverbal language (Munadi, 2013).

Heinich et al (Benny, 2017) suggest that there are 6 media classifications used for learning activities, namely print media, audio media, exhibition media, moving image media, multimedia, and based media. web / internet.

INSECTA Volume 1 Number 2, 2020 | p-ISSN 2722-8509 | e-ISSN 2722-8495

Copyright (C) 2020 Cips Nur Aini, Mohammad Wildan Habibi 
The availability of learning media will facilitate interaction between teachers and students so that learning activities will be more effective and efficient. Learning media that are made can arouse the curiosity of students. If you only listen to verbal information from the teacher, students will lack in understanding the subject matter well. Learning will be more meaningful if students are involved directly in the use of media. Where is the purpose of using the media during the learning process, namely so that students form their own concepts.

To determine a good learning process, the teacher is required to be able to master various methods and learning techniques. So that they are able to provide a good understanding, hardness, persistence, opportunity and quality and can provide changes in behavior and apply it in their lives. Based on the results of observations and interviews conducted at MTs Annuriyyah Kaliwining Jember, it was found that teachers had not used school facilities to develop learning media because educators only referred to one teaching material, namely in the form of worksheets, many students when learning science, especially biology material in student handbooks, namely In the form of worksheets, many do not understand because the material is quite a lot so that it seems that there are many writings and pictures that are not very clear.

When students open a learning textbook, what they find are pages filled with rows of small letters, sometimes complete with pictures or diagrams. All of it is structured with layout rigid in order to maximize the existing space. So that students better understand a concept if learning is presented not only in words but equipped with pictures (Mayer, 2008).

Therefore, practical learning media are needed and according to the needs of students. The results of observations in class VII students at MTs Annuriyah Kaliwining Jember stated that they preferred learning using image media and photographs and students prefer textbooks that are less written. From these observations it can be concluded that the student's learning style tends to be visual. In addition, the school is a pesantren-based school where students only get information from the LKS book and the material submitted by the teacher only.

From the above problems, we need an attractive learning media with concise and clear material that makes it easier for students to learn science. One of the interesting learning media is based learning media booklet. Booklet can be interpreted as a relatively small book containing practical information and knowledge about a particular subject or field of science (Rahmatih, 2017). Booklet is a small (A5) and thin book consisting of 48 pages of back and forth, containing writings and pictures (Hartanti, 2018). Term booklet comes from books and leaflet means media booklet is a blend of leaflet and a book with a small format (size) put together. Content structure booklet resembles a book (introduction, content, cover), it's just that the way of presenting the content is much shorter than a book. Booklet is one type of learning resource by design. Booklet can be used as a learning medium as long as the presentation is derived from the basic competencies (KD) that must be mastered by students, so that not too much content is designed to contain only one basic competency (Ahmad, 2018).

Booklet What is being developed is a printed media containing material that is more concise and structured using communicative language so that it is easily understood by students and is designed to be attractive so that students do not feel bored so that it fosters student reading interest. In addition, students can learn independently because booklet can be read anywhere and anytime so that it can help improve student understanding. Material on booklet namely the material of the interaction of living things with their environment because the material contains phenomena regarding the interaction of living things with their environment, besides that the material is also real or exists around the environment of students. So that this booklet media can present material on the interaction of living things with their environment in everyday life. Content structure booklet almost the same as a book

INSECTA Volume 1 Number 2, 2020 | p-ISSN 2722-8509| e-ISSN 2722-8495 Copyright @ 2020 Cips Nur Aini, Mohammad Wildan Habibi 
(introduction, content, cover), it's just that the way of presenting the content is much shorter than a book (Kevin, 2005).

This study aims to determine the validity of the media booklet and student responses to the media booklet.

\section{METHOD}

This study uses a research and development model Research and Development $(R \& D)$. The design of the development model in this study uses the 4D model (Define, Design, Development, and Dissemination) modified to 3D ( Define, Design, and Development) developed by Thiagarajan. This research was conducted from 15 April 2020 to 10 June 2020. The types of data in this study are qualitative data and quantitative data This research was conducted at MTs Annuriyah Kaliwining Jember. The subjects of this study were students of class VII. The small scale trial used 12 students of class VII A and VII B. The large scale trial used 27 students of class VII B.

This research step begins with a stage define ( definition) which consists of 5 steps, namely front end analysis, student analysis, task analysis, concept analysis and formulation of learning objectives, the second stage Design ( design) which consists of 3 steps, namely the selection of media in the form booklet, format selection in the form booklet, and initial design ( Draft I), last stage Development ( development) which consists of 3 steps, namely booklet validation by experts, stage 1 revision, small-scale trial, stage revision 2 , large-scale trials, stage 3 revisions, and the final product.

Data collection methods in this study using interviews and questionnaires. The interview method was used for initial observation and the questionnaire method was used to test the validity and test students' responses to the media booklet. The interview method was given to class VII science teachers, amounting to 1 person, for the questionnaire method was given to students with a small-scale test stage involving 12 students (each representative from class VII A and VII B) and a large-scale test stage involving 27 class students VII B using a scale rating likert 1-5. To test the validity of the booklet, it was validated by three experts, namely material experts. The aspects assessed were the aspects of the feasibility of content / material and language / readability; The media expert, the aspect being assessed, is the size aspect booklet, cover design booklet; content design booklet and material expert by

science teacher as for the aspects that were assessed, namely the aspects of the feasibility of content / material, language / readability and content design booklet. For data processing techniques at the validation stage, the formula is adapted from Sa'dun Akbar as follows:

Information :

$$
V-\mathrm{ah}=\frac{T s e}{T s h} 100 \%
$$

$\mathrm{V}$-ah: percentage value

Tse : total empirical score obtained from expert

Tsh : expected total score

The criteria for testing the validity of instructional media can be seen in the table below which was adapted from Akbar (2013).

Tabel 1. Kriteria Uji Kelayakan

\begin{tabular}{ll}
\hline \multicolumn{1}{c}{ Percentage (\%) } & \multicolumn{1}{c}{ Criteria } \\
\hline $81 \%-100 \%$ & Very valid, or can be used without Valid revisions, or can be \\
$61 \%-80 \%$ & used but needs minor revisions \\
$41 \%-60 \%$ & Less valid, not used because it needs major revisions \\
$21 \%-40 \%$ & Not valid, or may not be used Very invalid, may \\
$0 \%-20 \%$ & not be used \\
\hline
\end{tabular}

INSECTA Volume 1 Number 2, 2020 | p-ISSN 2722-8509 | e-ISSN 2722-8495

Copyright () 2020 Cips Nur Aini, Mohammad Wildan Habibi 
For data processing techniques at the student response test stage, the formula is adapted from Sa'dun Akbar as follows:

$$
V-\mathrm{au}=\frac{T s e}{T s h} 100 \%
$$

Information :

$\mathrm{V}$-au: percentage value

Tse : total empirical score obtained from expert

Tsh : expected total score

Untuk kriteria hasil respon siswa terhadap media booklet dapat dilihat pada tabel sebagai berikut:

Tabel 2. Kriteria Hasil Respon Siswa

\begin{tabular}{ll}
\hline Percentage (\%) & \multicolumn{1}{c}{ Criteria } \\
\hline $81 \%-100 \%$ & Very interesting \\
$61 \%-80 \%$ & Interesting \\
$41 \%-60 \%$ & Quite interesting \\
$21 \%-40 \%$ & Not attractive \\
$0 \%-20 \%$ & Very Unattractive \\
\hline
\end{tabular}

(Akbar, 2013)

\section{RESULTS ANS DISCUSSION}

The results of the study with the title "Development of Science-Based Learning Media Booklet for SMP ", has developed and obtained the results of assessment data by experts on the media booklet. Result of media development booklet ins get advice and comments from experts both from material expert validators, media experts, and material experts by the teacher. The revised results of input from experts are shown in the following figure:

Table 3. Revision of Media Booklet Products

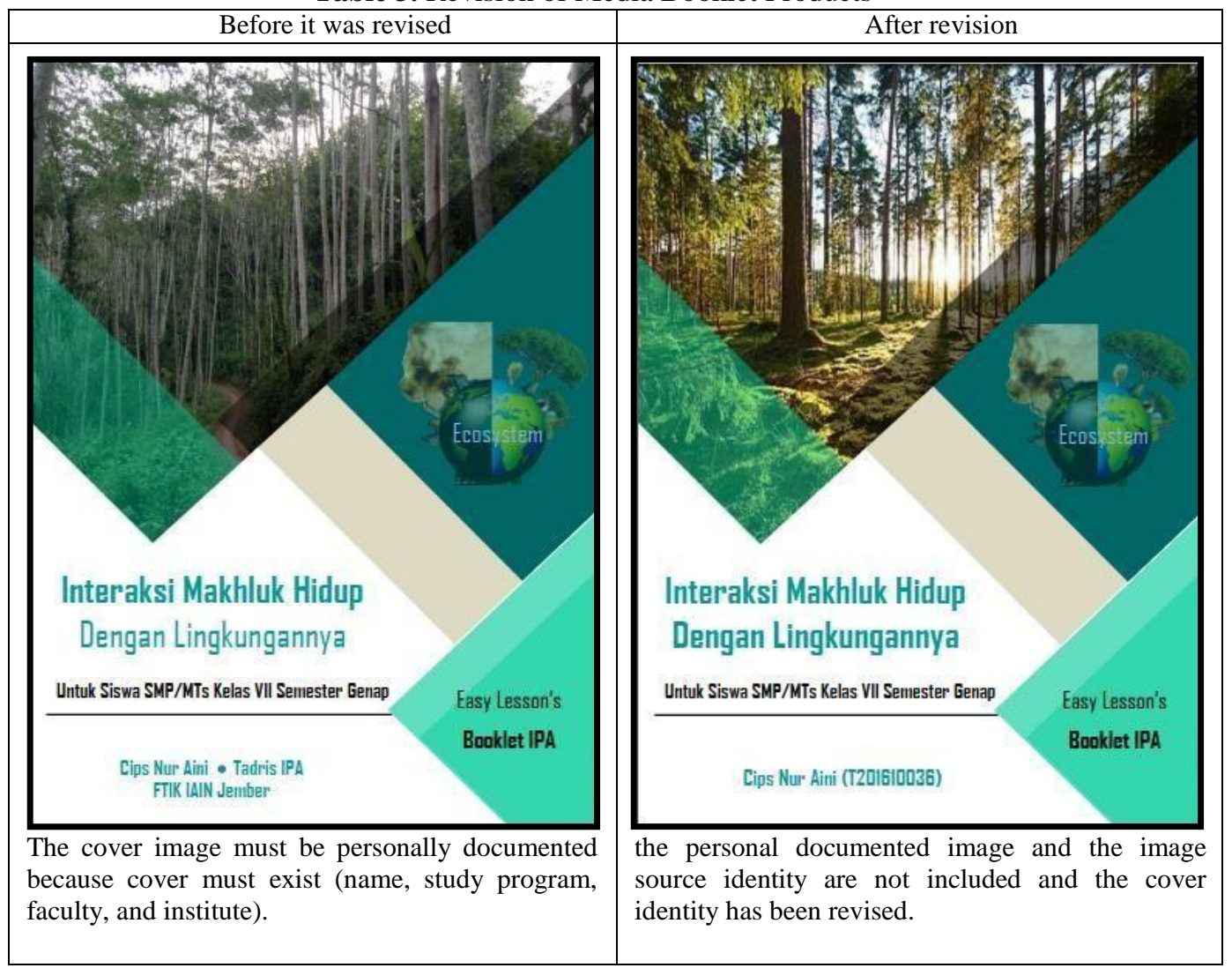

INSECTA Volume 1 Number 2, 2020 | p-ISSN 2722-8509| e-ISSN 2722-8495 Copyright (c 2020 Cips Nur Aini, Mohammad Wildan Habibi 




On the back cover page; publisher naming is not included with the name of the school studied. do not include the name of the school booklet this can be used other than the school which is researched.

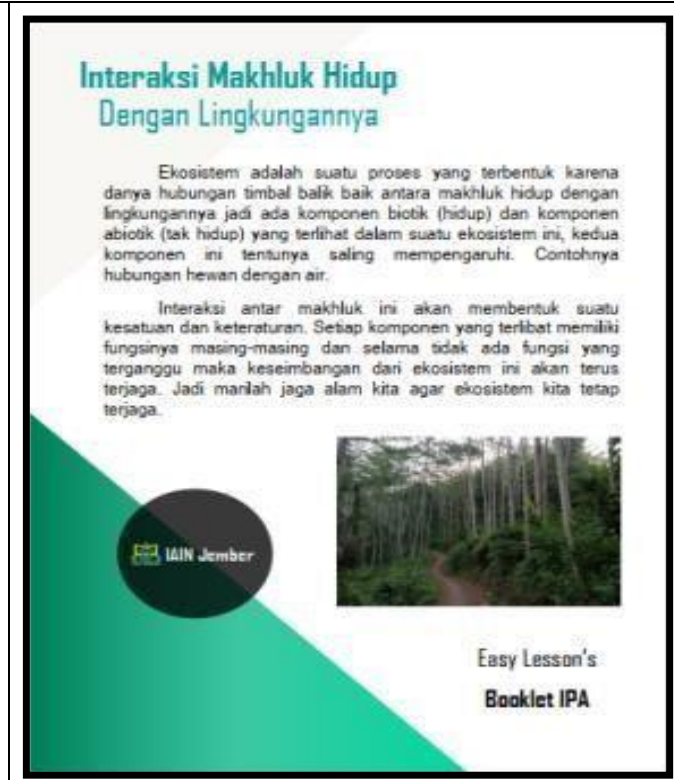

On the back cover page; publisher naming So that booklet this can be used other than the school under study. The purpose of this fix is in order booklet more that is researched.

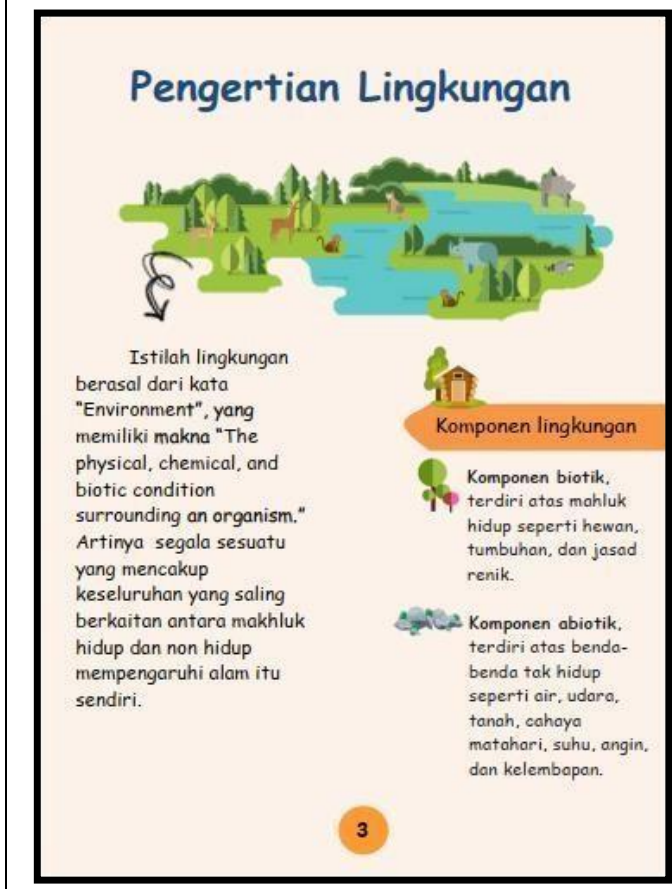

The writing or the "environment" change has bee $\mathrm{n}$ replaced with writing of the "environmental concept".

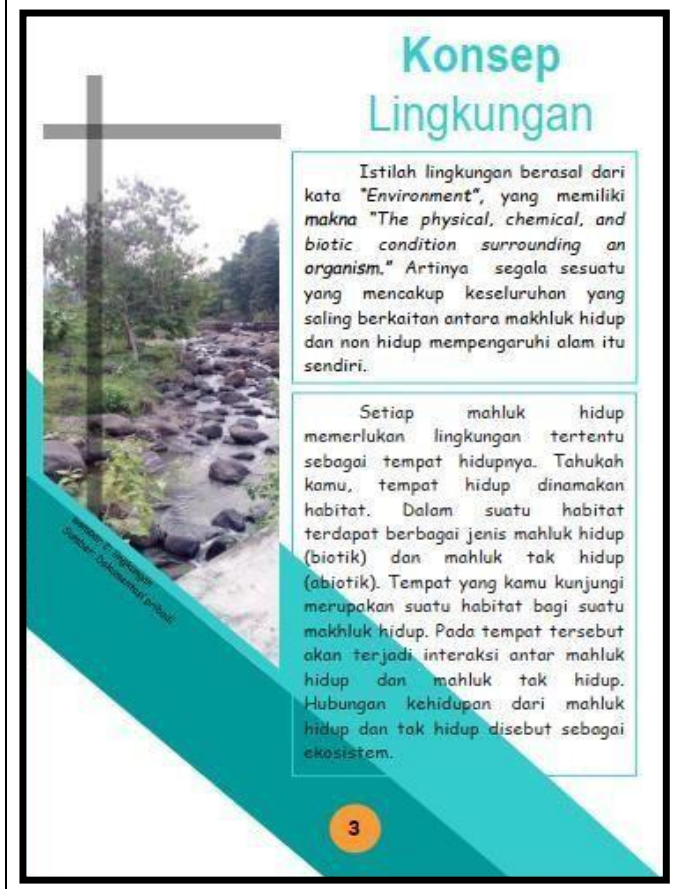

The writing or the "environment" revisied.

INSECTA Volume 1 Number 2, 2020 | p-ISSN 2722-8509 | e-ISSN 2722-8495

Copyright () 2020 Cips Nur Aini, Mohammad Wildan Habibi 


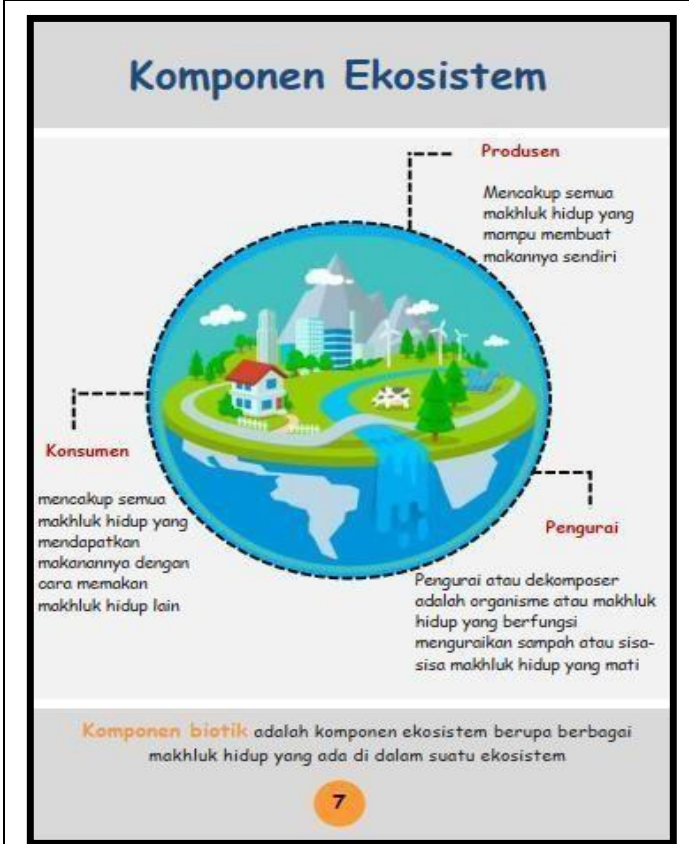

On the component, the image and description are not representative.

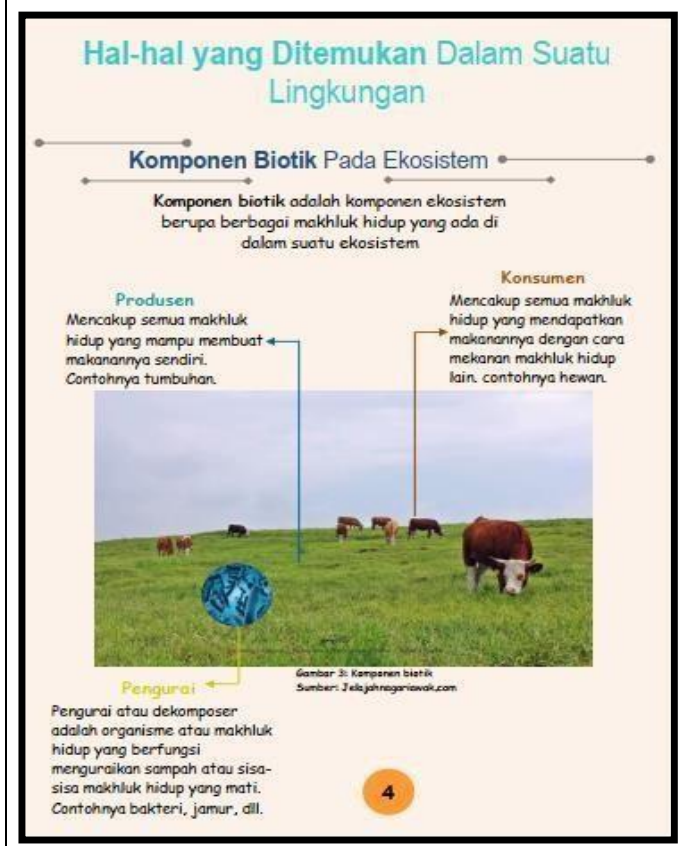

on the biotic component, the image and description are repressent.

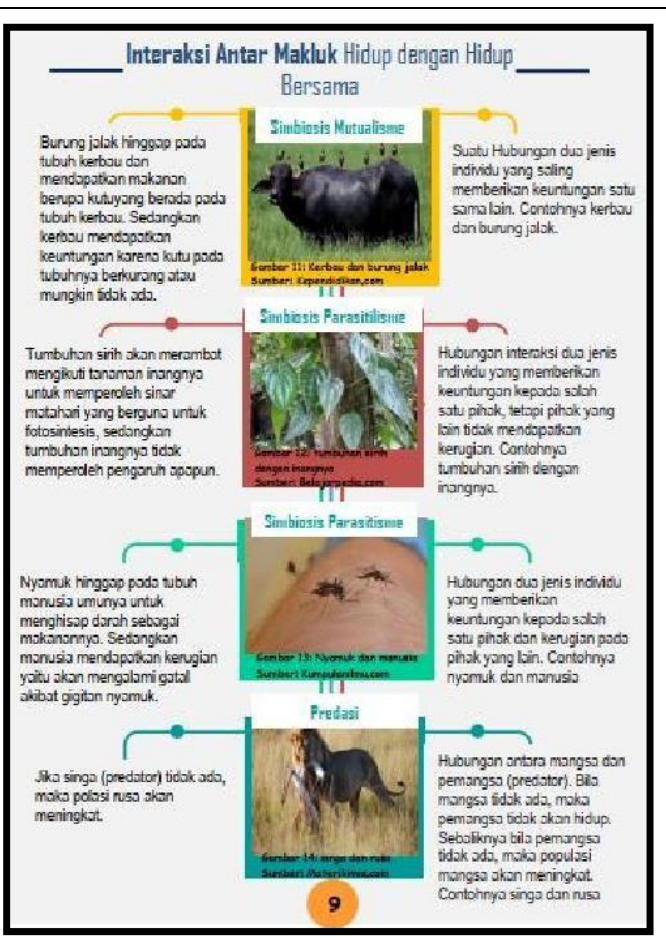

For image has include the reasons why it must be explained why take example that and picture even included a description of the image and the source of the image. 


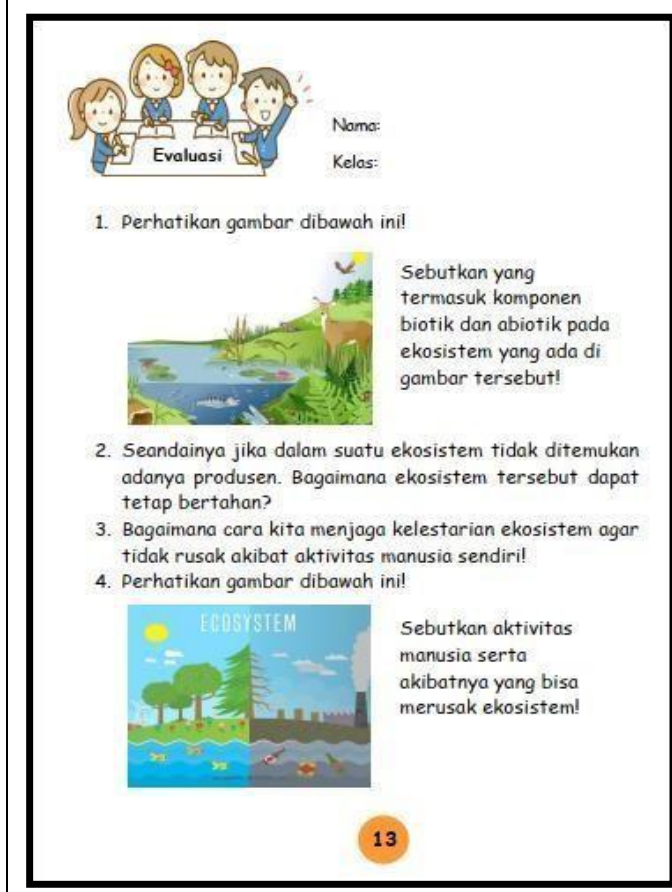

The evaluation questions should be in accordance with the evaluation questions that have represented each learning. If indicator 5 then about the learning indicator. at least 5 to represent each indicator.

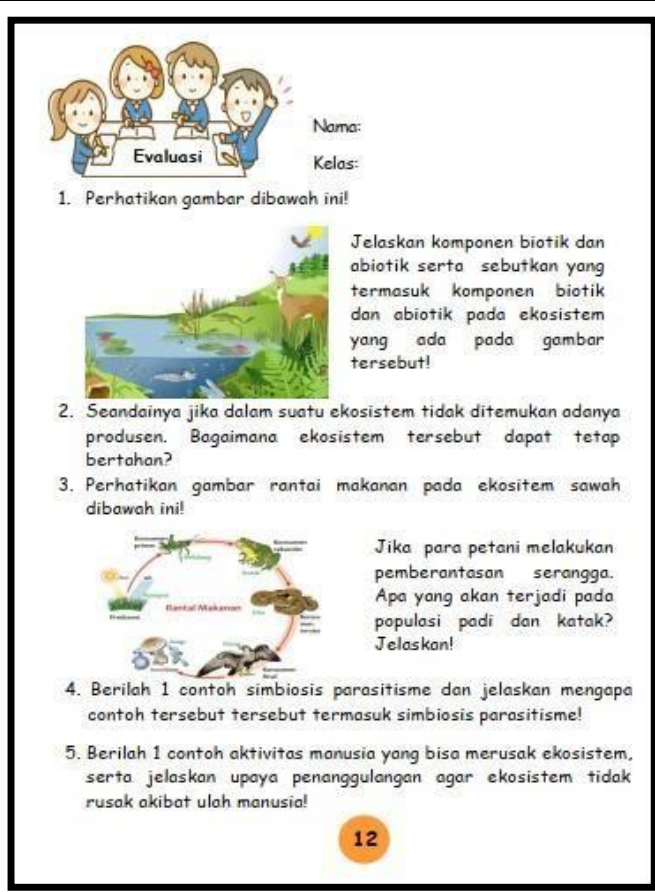

The evaluation questions revisied.

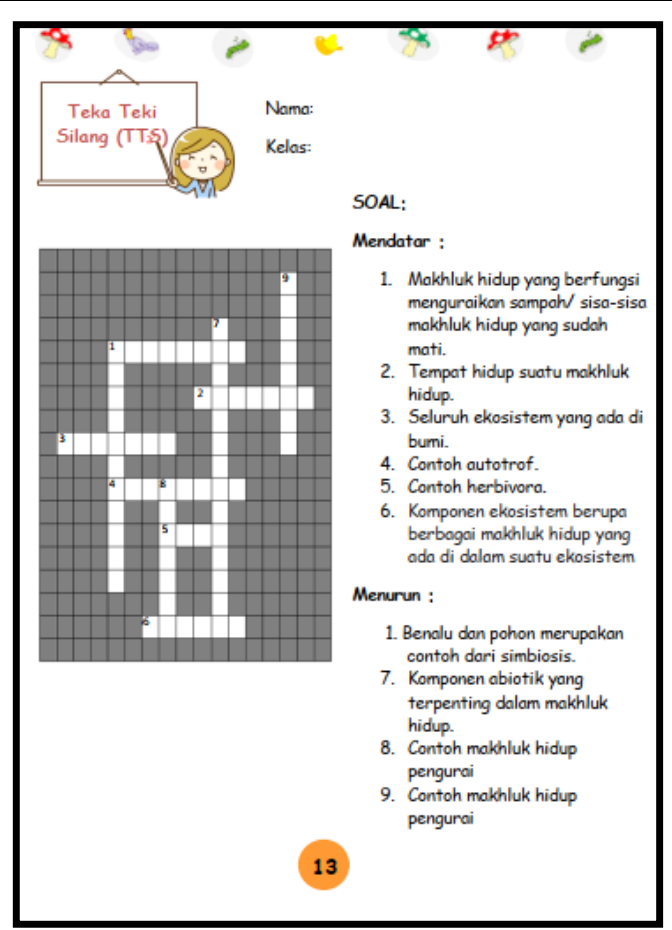

TTS questions must have horizontal questions and declining questions

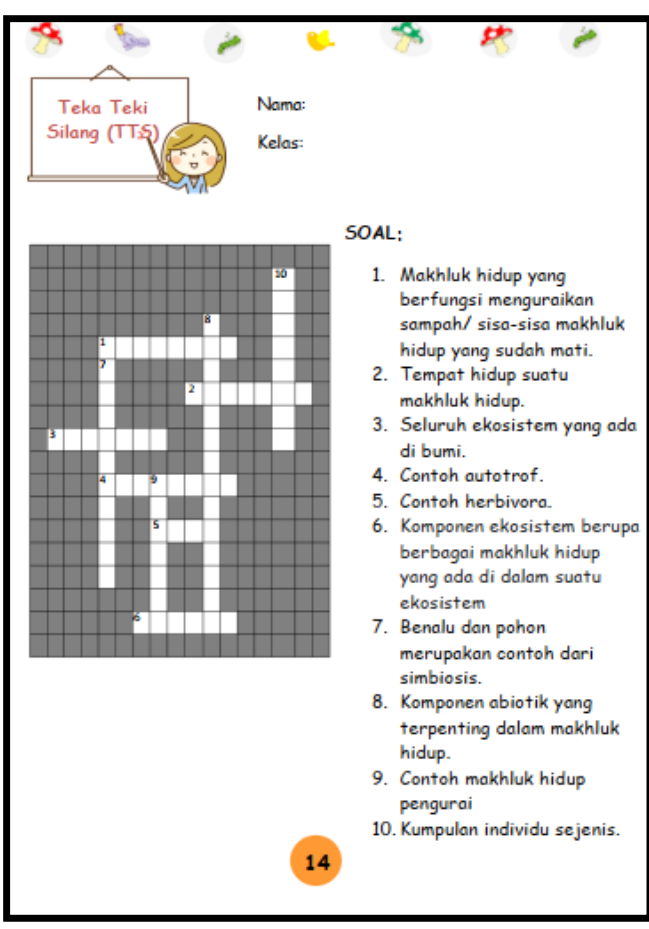

In the TTS questions there must be horizontal questions and declining questions in order to make it easier for students to do. 

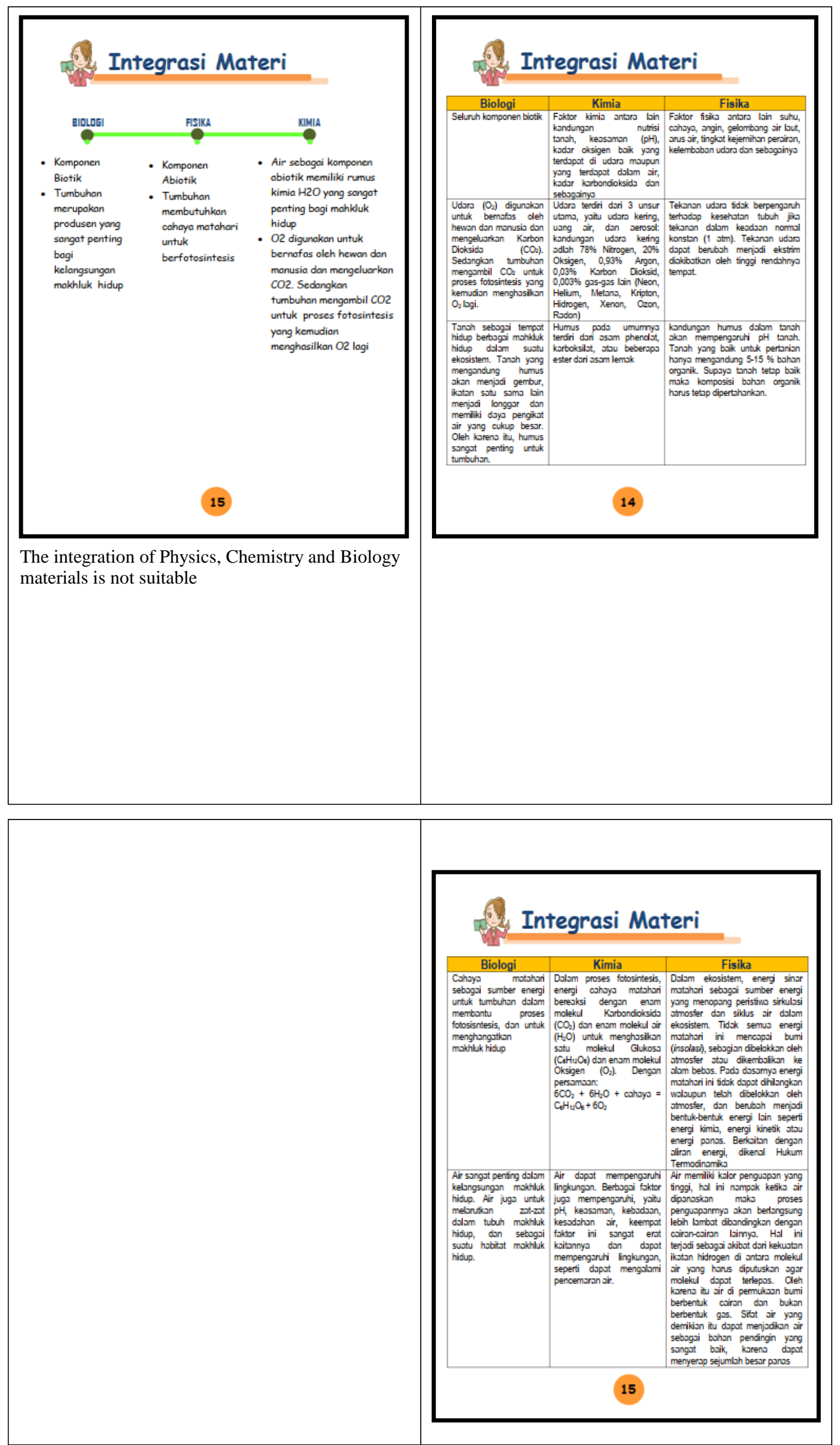

INSECTA Volume 1 Number 2, 2020 | p-ISSN 2722-8509| e-ISSN 2722-8495 Copyright (c 2020 Cips Nur Aini, Mohammad Wildan Habibi 


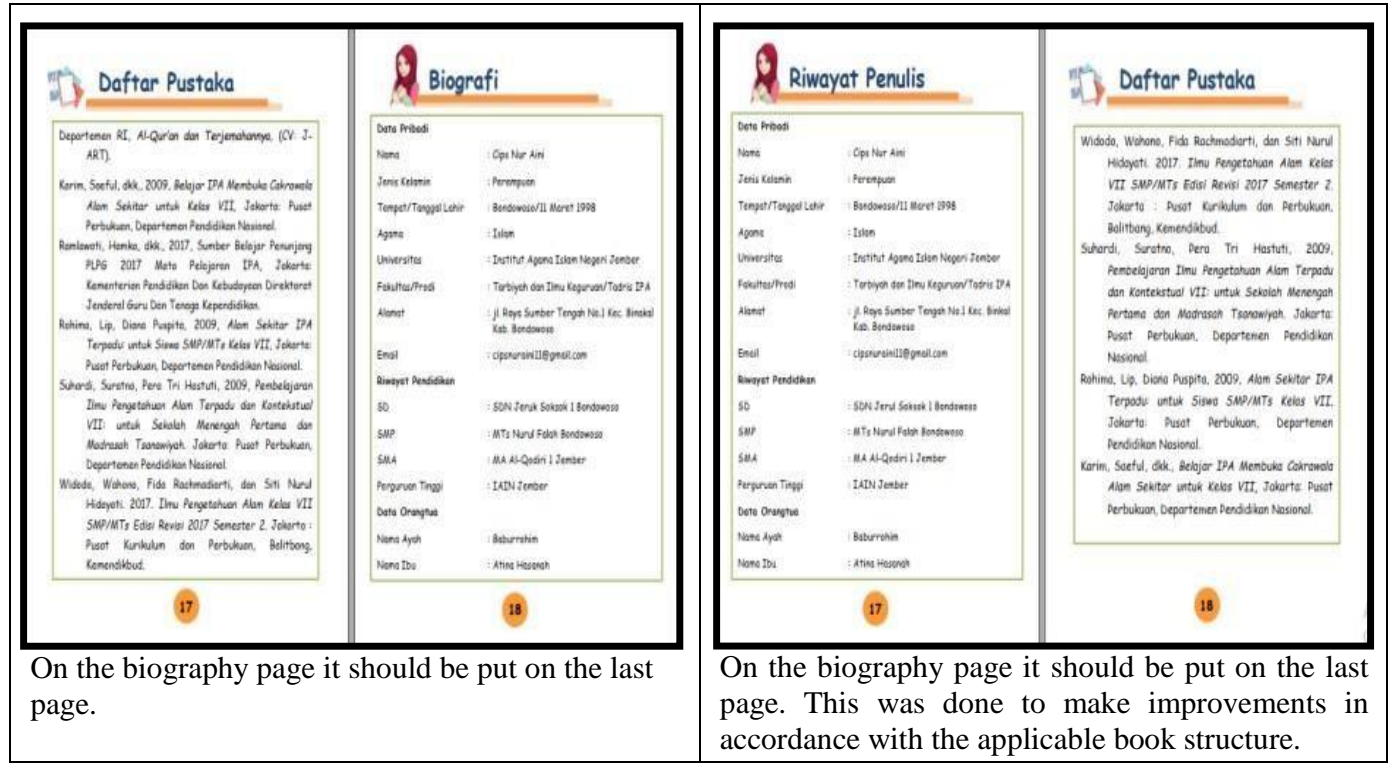

1. Product Validation

At the product validation stage on the media booklet each done 2 times. The second stage assessment as a determinant or final stage assessment is focused on the completeness of the components both from the total score, percentage, and criteria. The results of the validator's assessment of the media booklet as follows:

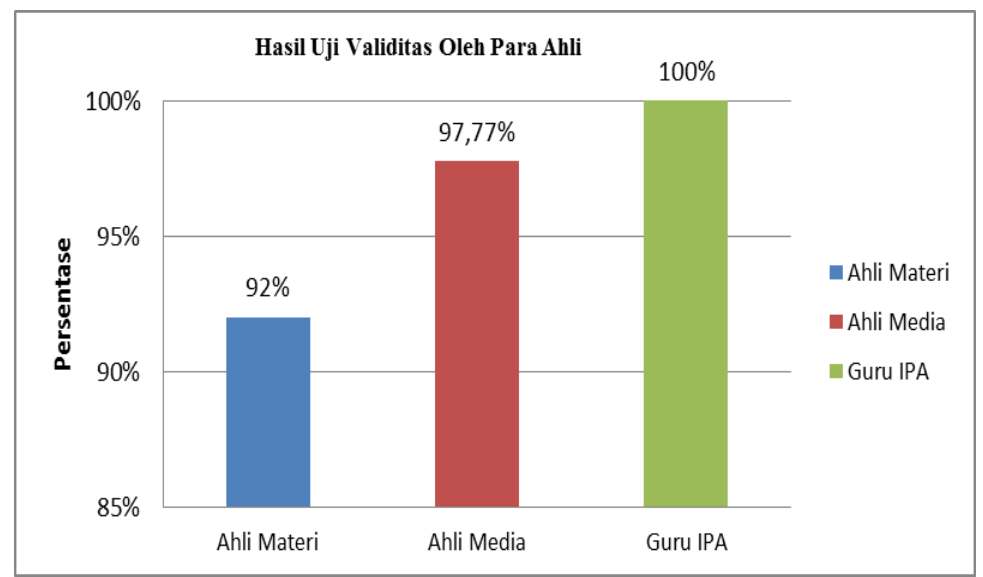

Figure 1. Recapitulation Of Media Assessment Results Data Booklet

Based on the recapitulation of the second assessment result data from material experts, it was obtained a percentage of $92 \%$ with a very valid category meaning media booklet valid to use as a learning medium. The assessment from media experts obtained a percentage of $97.77 \%$ with a very valid category, meaning media booklet valid to use as a learning medium and the assessment of material experts by science teachers obtained a percentage of $100 \%$ with a very valid category meaning media booklet valid to use as a learning medium. Media is said to be valid if it is in the range $\geq 61 \%$ (Bintiningtyas, 2018). So it can be concluded that the media developed is in the form of media booklet is valid for use.

2. Test Student Response

Student responses are students' responses to the media booklet that was developed. The results of the student response test to the media booklet as follows: 
Table 4. Student Response Data towards Booklet

\begin{tabular}{cccc}
\hline No. & Testing & Percentage of Response & Criteria \\
\hline 1 & Small scale & $91,06 \%$ & Very interesting \\
2 & Large scale & $92,72 \%$ & Very interesting
\end{tabular}

The data obtained from the student response questionnaire on small-scale trials and large-scale trials showed the percentage of $91.96 \%$ and $92.72 \%$, respectively. From the data, the results of small-scale trials and large-scale trials are in the very interesting category, respectively. This is supported by the research of Wicaksono (2014) which states that the category of student responses that shows more than $50 \%$ of the questions with strong or very strong criteria, it can be concluded that the developed learning media gets a positive response from students. The positive response also shows that the learning media booklet developed can make students more understanding, able to learn independently, actively, and have, and have a high interest in learning. This is supported by research conducted by Setyaningsih et al. (2019) who concluded that the development of science-based learning media booklet worthy of use and media booklet can attract students' interest to learn because it gets a positive response from students.

In this study, the application of science-based learning media booklet At MTs Annuriyah Kaliwining Jember, Class VII has received a positive response from students towards the booklet media. Booklet It is arranged in an attractive design which contains material on the interaction of living things with their environment. Booklet This is a small size, namely A5 size, which is equipped with interesting descriptions and pictures booklet easy to carry everywhere and the media booklet This uses communicative language so that students can easily understand what is conveyed in the media. This is in line with the research of Rahmatih et al. (2017) which states that booklet easy to carry anywhere because of its small size, equipped with concise and systematic explanations, and pictures that make it easier for students to understand a concept. Basically presentation booklet it uses lots of images and colors to give it an attractive appearance. This is supported by research by Pralisaputri et al. (2016) which states that students tend to prefer interesting reading with few descriptions and lots of pictures / colors.

Content / content in media booklet developed, namely structured systematically and clearly in order to make it easier for students to learn. This is in accordance with the statement of Sariani et al. (2017) in their research which states that media development must be designed systematically, this is so that the role of the media as a learning support tool can be achieved effectively. And this is also supported by the opinion of Istifarida et al. (2017) in their research which states that learning media must contain clear content so that learning material can be conveyed effectively. Also on booklet This is accompanied by material integration both in the integration of materials in physics, chemistry, biology and integration in the Qur'an. The goal is that students know that one material has a lot to do with or is related to other sciences. And in this knowledge it has been described or contained in the Qur'an. So this makes students know and believe that the Qur'an has been around for a long time and what is stated in the Qur'an is true

Media booklet The material for the interaction of living things with their environment is also accompanied by pictures of personal documentation as well as other real pictures which are expected to foster student awareness of protecting the environment and protecting the ecosystem from being damaged. By presenting material on the interaction of living things with their environment in the media booklet students can have an attitude of awareness and care for the environment to improve the quality of education in the learning process which is associated with events that match the reality of the environment to maintain and preserve the existing ecosystem. So that this learning can make learning meaningful to students. learning is said to be meaningful if learning

INSECTA Volume 1 Number 2, 2020 | p-ISSN 2722-8509| e-ISSN 2722-8495

Copyright (C) 2020 Cips Nur Aini, Mohammad Wildan Habibi 
can be applied in everyday life.

In science learning media products booklet which has been developed is equipped with several advantages including:

1. Media booklet character portable because it is easy to carry anywhere and its shape small and thin. And booklet it is printable and can also be softfile so that students can study anywhere and anytime. And students can also learn at their own ability and speed.

2. Booklet this is systematic, as in textbooks and textbooks booklet this is served with communicative language to make it easier for students to learn.

3. Booklet This is accompanied by an evaluation in the form of a Cross Puzzle (TTS) aims to review material that has been studied. With this TTS, students have more fun working on questions.

4. Booklet equipped with material integration both material integration in Physics, Chemistry, Biology and the integration of the Qur'an.

5. Media booklet easy to obtain because booklet this can take the form hardfile with how to print and can also on line by means of download link media booklet which has been provided.

6. Media booklet can be used in schools that support gadget or not at all.

\section{CONCLUSION}

Based on the results of the research that has been done, it can be concluded that the science-based learning media booklet In terms of the interaction between living things and their environment, it is in the very good category. So that booklet suitable for use as a learning media for Science Biology in class VII MTs / SMP.

\section{REFERENCE}

Personal, B. (2017). Media and Technology in Learning. Jakarta: Kencana.

Azhar, A. (2004). Learning Media. Jakarta: PT. Rajagrafindo Persada.

Azhar, A. (2019). Revised Edition Learning Media. Jakarta: PT. Raja Grafindo Persada.

Balqis, A. (2018). Validity of Booklet Media Based on Ethnoscience Sub Material Physical Properties and Chemistry and Change for Class VII SMP. E-Journal Unesa, (2), 1.

Bintiningtyas, L.A. (2016). Varmintz Chemistry Game Development A Learning Media on the Periodic System Material of the Elements. Unesa Journal Of Chemical Education, 5(2), 7.

Agustini, A. D. (2015). Application of the CLIS Model with Booklets on Results Student Learning on Digestive System Material in Junior High School. Research Articles, 4.

Djamarah, S.B. (2006). Teaching and Learning Strategies. Jakarta: PT Rineka Cipta.

Istifarida, B., et al. (2017), Development of E-Book Based on Problem Based Learning- GIS To Improve Spatial Thinking Skills in Class X Students of SMA N 1 Sragen 2016/2017. GeoEco Journal, 3(2), 3.

Jalinus, N., et al. (2016). Media and Learning Resources. Jakarta: Kencana.

Mahendrani, K. \& Sudarmin. (2015). Development of Themes Photography Ethnoscience Booklet Ecosystems to Improve Learning Outcomes in Junior High School Students. Unnes Science Education Journal, 4(1), 4.

Munadi, Y. (2013). Learning Media. Jakarta: GP Press Group.

Mayer, R.E. (2009). Multimedia Learning Principles and Application. Surabaya: ITS Pres.

Nurrita, T. (2018). Development of Learning Media to Improve Results Student Learning. Journal: Misykat, 3(1), 3.

Paramita, R., Ariyati, E. (2018). Inventory Result Booklet Development Medicinal Plants as Learning Media for the Benefits of Biodiversity. Journal of Science and Learning Science, $2(2), 1$.

Pralisaputri, K.R., et al. (2016). SETS Based Booklet Media Development on Main Material Mitigation

INSECTA Volume 1 Number 2, 2020 | p-ISSN 2722-8509 | e-ISSN 2722-8495

Copyright (c 2020 Cips Nur Aini, Mohammad Wildan Habibi 
and Adaptation and Adaptation of Natural Disasters for Grade X SMA. GeoEco Journal, 2 (2), 4.

Rahmatih, A.N. (2017). Booklet Development Based on Potential Studies and Local Problems as Teaching Materials for Agricultural Vocational Schools. Journal of Innovative Science Education, 6(2), 16.

Rukmana, Hartanti Indah. (2018). Feasibility of Media Booklet Submaterial of Diversity Live Class X High School. Research Articles. 2.

Sariani, N. et al. (2017). Development of a Care-Based Geography Learning Module Student Environment on Natural Resources Material in Class XI IPS Bina Utama Pontianak, GeoEco Journal, 3(1), 4.

Setyaningsih, E. (2019). Development of Media Booklet Based on Kalimantan Local Potential West on the Material of Biodiversity in Class X Students at SMA Muhammadiyah 1 Potianak. Journal of Biological Pedagogy, 3(1), 1.

Simangunsong, T. \& Mukhtar. (2015). Development of Learning-Based Media Multimedia in Science Subjects in Junior High Schools. 2(4), 4.

Tafonao,T. (2018), The Role of Learning Media in Increasing Learning Interest College Student. Journal of Educational Communication, 2(1), 2.

Wicaksono, P., et al. (2014). Development of Mathematics Learning Tools Speaking English Based on Multiple Intelligences in Block and Cube Material for Class VII Junior High School. Mathematics Learning Electronic Journal, 2(5), 5.

Yani, Ahmad, et al, (2018), The Effectiveness of the Scientific Approach with the Higher Media Booklet Order Thinking Against Biology Learning Outcomes of High School Students in Wajo Regency, Journal of Biology Science \& Education, 7(1), 4. 